\title{
Characterization of gypsum plasterboard with polyurethane foam waste reinforced with polypropylene fibers
}

\author{
L. Alameda, V. Calderón, C. Junco, A. Rodríguez, J. Gadea, S. Gutiérrez-González $₫$ \\ Departamento de Construcciones Arquitectónicas e Ingeniería de la Construcción y del Terreno, \\ Universidad de Burgos, (Burgos, Spain) \\ \sggonzalez@ubu.es
}

\author{
Received 22 July 2015 \\ Accepted 7 April 2016 \\ Available on line 19 September 2016
}

\begin{abstract}
Gypsum plasterboard that incorporates various combinations of polyurethane foam waste and polypropylene fibers in its matrix is studied. The prefabricated material was characterized in a series of standardized tests: bulk density, maximum breaking load under flexion stress, total water absorption, surface hardness, thermal properties, and reaction to fire performance. Polypropylene fibers were added to the polyurethane gypsum composites to improve the mechanical behavior of the plasterboard under loading. The results indicate that increased quantities of polymer waste led to significant reductions in the weight/surface ratio, the mechanical strength and the surface hardness of the gypsum, as well as improving its thermal resistance. The polypropylene fibers showed good adhesion to the polymer and the gypsum matrix, which enhanced the mechanical performance and the absorption capacity of these compounds. The non-combustibility test demonstrated the potential of the new material for use in internal linings.
\end{abstract}

KEYWORDS: Gypsum plasterboard; Polyurethane foam waste; Polypropylene fibers; Non-combustibility test

Citation/Citar como: Alameda, L.; Calderón, V.; Junco, C.; Rodríguez, A.; Gadea, J.; Gutiérrez-González, S. (2016) Characterization of gypsum plasterboard with polyurethane foam waste reinforced with polypropylene fibers. Mater. Construcc. 66 [324], e100. http://dx.doi.org/10.3989/mc.2016.06015.

RESUMEN: Caracterización de placas de yeso con residuos de espuma de poliuretano reforzadas con fibras de polipropileno. Este artículo presenta un estudio experimental basado en la reutilización de residuos de poliuretano en una matriz de yeso para elaborar una placa de yeso laminado. Las placas fueron caracterizadas mediante los ensayos normalizados de densidad aparente, carga de rotura máxima a flexión, absorción total de agua, dureza superficial y reacción al fuego. Se han introducido fibras de polipropileno en la matriz con el objetivo de aumentar la resistencia mecánica del material. Los resultados muestran que el incremento de residuo polimérico en el material implica importantes reducciones de peso, resistencia mecánica y dureza superficial, a la par que se mejora su resistencia térmica consiguiéndose valores similares a los comerciales. Las fibras de polipropileno mostraron una buena adhesión con el polímero, mejorando el comportamiento mecánico y la capacidad de absorción. El ensayo de reacción al fuego confirmó que los residuos de poliuretano pueden ser empleados en la fabricación de placas de yeso laminado en cumplimiento con la normativa.

PALABRAS CLAVE: Placas de yeso; Residuo de espuma de poliuretano; Fibras de polipropileno; Ensayo de no combustibilidad

Copyright: (C) 2016 CSIC. This is an open-access article distributed under the terms of the Creative Commons Attribution License (CC BY) Spain 3.0. 


\section{INTRODUCTION}

Prefabricated gypsum products have increasingly been used in construction over recent years, fundamentally because of their environmental benefits as lightweight products, which imply savings on materials and haulage costs, and greater ease of on-site assembly. Moreover, the fire retardance properties of these products are generally very good $(1,2)$. Gypsum plasterboards (GPB) are extensively used as internal partitions and ceilings. Their use permits effective spatial layouts inside buildings, thereby improving living conditions and safety (3). Waste management is an acute problem in modern-day society, due to rising demand for goods and services, both in industrialized countries and in the so-called emerging economies. Increasing amounts of solid waste are produced, placing constraints on the availability of landfill sites, with a consequent rise in disposal and dumping costs (4). The current research examines the viability of introducing various wastes of industrial origin in a gypsum matrix (5-8). The aim is to reduce the weight of the gypsum and to improve its thermal properties. All of this has the purpose of obtaining lightweight, insulation materials that outperform conventional materials, reducing haulage costs, improving energetic efficiency, and exploiting recycled waste products (that would otherwise be dumped). A lighter weight that allows quicker assembly and improved thermal characteristics that require no further insulative layers, represent two implicit advantages of these materials in prefabricated products $(9,10)$. Numerous references in the literature refer to the incorporation of different waste products in prefabricated plasterboard, in order to improve certain physical and mechanical properties. The use of Expanded Polystyrene (EPS) as a shredded material added to the gypsum plasterboard matrix was analyzed in (11). This waste product is a by-product of packaging collected from municipal recycling schemes that is subsquently milled. Other studies have been conducted on construction panels prepared with a mixture of gypsum rubber from end-of-life tires (12) and gypsum cork waste (13), both of which are characterized by their low density, as well as on the addition of recycled paper to plasterboard (14). Polyurethane foam waste has been studied in lightweight plaster materials with enhanced thermal properties in (15), although no references have been found on the use of this type of waste in the preparation of gypsum plasterboard.

The objective of this study is to examine the reuse of polyurethane waste, which is incorporated in the gypsum matrix, for the manufacture of prefabricated elements. We also aim to study the effect of polypropylene fibers on the mechanical properties of those elements. Several different types of fibers such as polypropylene fiber, polyamide fiber, and glass fiber have been extensively used in gypsum boards because of their specific advantages (16-18), although no results have been reported on the use of both polyurethane and polymeric fibers. The challenge is to manufacture lightweight gypsum plasterboard for use in the construction industry, thereby improving the thermal properties of these traditional materials and, at the same time, recycling polymer wastes, which would otherwise be dumped in landfill sites.

\section{RAW MATERIALS}

\section{Gypsum}

Construction gypsum is classified as B1/20/2 in Standard EN 13279-1 (19), the specifications of which stipulate an initial setting period of over 20 minutes, with a compression resistance of $\geq 2 \mathrm{~N} / \mathrm{mm}^{2}$. According to the manufacturer's specifications, this gypsum presents a purity value of $87.66 \%$. X-Ray Diffraction (XRD) for the purposes of mineralogical characterization identified calcium sulfate hemihydrate as its main component. The real density stood at $2320 \mathrm{~kg} / \mathrm{m}^{3}$ and laser diffraction of the granulometry indicated that $50 \%$ of the sample presented sizes of below $50 \mu \mathrm{m}$.

The gypsum was first oven-dried at $40 \pm 2{ }^{\circ} \mathrm{C}$ over 24 hours; after cooling and homogenization, it was placed in a watertight container for use in the tests.

\section{Polyurethane foam waste}

Polyurethane Foam Waste (PFW) was taken from waste generated in the manufacture of insulative panels in the refrigeration and construction industries. Following crushing, it is presented as a dust with a granulometry of between $0-0.5 \mathrm{~mm}$, with real density and bulk density values of $1080 \mathrm{~kg} / \mathrm{m}^{3}$ and $72 \mathrm{~kg} / \mathrm{m}^{3}$, respectively.

\section{Polypropylene fibers}

The PP fibers (F2) were supplied by Grupo Pumma (Paviland $\mathbb{R})$. The fibers were approximately $30 \mu \mathrm{m}$ in diameter and $12 \mathrm{~mm}$ in length with a tensile strength ranging between 300 and $400 \mathrm{MPa}$. Elemental analysis (CHNS) indicated the presence of carbon, hydrogen, nitrogen and sulfur in the fiber. In (Table 1), a Scanning Electron Microscopy (SEM) image shows the fiber alignments and dimensions.

\section{EXPERIMENTAL}

\section{Specimen preparation of the Gypsum Plasterboard ( $G P B)$}

The sample reference numbers, fiber percentages, and the Polyurethane Foam Waste/plaster (PFW/p) ratio by volume of each sample are listed in (Table 2). 
TABLE 1. Elemental analysis (CHNS) and SEM of PP fibres

\begin{tabular}{lcccc}
\hline Element & Carbon & Hydrogen & Nitrogen & Sulfur \\
\hline$\%$ & 85.57 & 14.31 & 0.08 & 0.04 \\
SEM & & & \\
\hline & & & & \\
\hline
\end{tabular}

TABLE 2. GPB Samples, volume ratio, water/conglomerate ratio, weight/surface ratio, bulk density, surface hardness and water absorption

\begin{tabular}{|c|c|c|c|c|c|c|c|}
\hline Series no. & Sample & $\begin{array}{c}\text { Volume } \\
\text { ratio (PFWI } \\
\text { plaster) }\end{array}$ & $\begin{array}{c}\text { Waterl } \\
\text { (conglomerate) } \\
\text { ratio }\end{array}$ & $\begin{array}{c}\text { Weight/ } \\
\text { surface } \\
\text { ratio }\left(\mathrm{Kg} / \mathbf{m}^{2}\right)\end{array}$ & $\begin{array}{c}\text { Bulk } \\
\text { density } \\
\left(\mathrm{Kg} / \mathrm{m}^{3}\right)\end{array}$ & $\begin{array}{c}\text { Surface } \\
\text { Hardness } \\
\text { (Avg. Ø, mm) } \\
\end{array}$ & $\begin{array}{c}\text { Water } \\
\text { Absorption } \\
\text { (Avg.\%) }\end{array}$ \\
\hline "Comercial & GPB ST & - & - & 9.60 & 744 & 16.33 & 31.87 \\
\hline Reference & GPB RS & $0 / 1$ & 0.47 & 21.23 & 1416 & 11.33 & 27.36 \\
\hline \multirow{3}{*}{$\begin{array}{l}\text { Series I } \\
(0 \% \text { F2) }\end{array}$} & GPB0.5 & $0.5 / 1$ & 0.52 & 19.45 & 1297 & 13.22 & 32.66 \\
\hline & GPB1 & $1 / 1$ & 0.60 & 18.03 & 1202 & 14.33 & 40.81 \\
\hline & GPB2 & $2 / 1$ & 0.82 & 14.32 & 955 & 16.56 & 61.59 \\
\hline \multirow{4}{*}{$\begin{array}{l}\text { Series II } \\
(2 \% \text { F2) }\end{array}$} & GPB RS2F2 & $0 / 1$ & 0.47 & 18.90 & 1350 & 9.83 & 21.15 \\
\hline & GPB0.5 2F2 & $0.5 / 1$ & 0.52 & 17.96 & 1283 & 11.00 & 25.59 \\
\hline & GPB1 2F2 & $1 / 1$ & 0.60 & 16.87 & 1205 & 12.89 & 32.03 \\
\hline & GPB 2 2F2 & $2 / 1$ & 0.82 & 13.44 & 960 & 18.11 & 51.31 \\
\hline \multirow{4}{*}{$\begin{array}{l}\text { Series III } \\
(4 \% \text { F2) }\end{array}$} & GPB RS4F2 & $0 / 1$ & 0.47 & 20.26 & 1447 & 9.44 & 21.41 \\
\hline & GPB0.5 4F2 & $0.5 / 1$ & 0.52 & 19.05 & 1361 & 10.89 & 26.00 \\
\hline & GPB1 4F2 & $1 / 1$ & 0.60 & 17.70 & 1264 & 12.44 & 32.91 \\
\hline & GPB2 4F2 & $2 / 1$ & 0.82 & 14.46 & 1033 & 16.44 & 50.91 \\
\hline
\end{tabular}

(*) Comercial Standard Plasterboard Type A (EN-520)

The mixtures were prepared by partial substitution of the gypsum for the waste product in amounts of $0.5,1$, and 2 parts by volume ( $\mathrm{p}+\mathrm{PFW})$. They were then tested on the shaking table (slump-flow test, with an average spreading diameter of $165 \pm 5$ $\mathrm{mm}$ ), to determine the quantity of water needed for acceptable workability (Table 2). Suitable admixtures were also employed to enhance workability.
A series of reference specimens were manufactured with no waste products in their components (GPB RS), to quantify the effects of the waste aggregates on the prefabricated products. Commercial plasterboard (GPB ST) was also analyzed under the same conditions as the plasterboard investigated in this paper; although its complex mixture of raw materials (paperboard, additives, lighteners, fibers) 
significantly influenced the final results that were only taken as a reference.

The procedure to prepare gypsum plasterboard (GPB) consisted of progressive additions of PFW to the plaster, in substitution of the various proportions of gypsum by volume $(1 / 1,1 / 0.51 / 2)$. The dry components were homogenously mixed, after which the water was added and mixed in line with standard EN 13279-2 (20). A series of $(300 \times 400 \times 15 \mathrm{~mm})^{3}$ molds were filled with the mixture and any excess wiped away, to accelerate the drying process. In this way, a series of three specimens for each dosage and each test were prepared to conduct the tests.

Finally, after curing at a temperature of $24{ }^{\circ} \mathrm{C}$ and at a relative humidity of $50 \pm 1 \%$ for 7 days, all the test specimens were then dried to a constant mass at $40 \pm 2{ }^{\circ} \mathrm{C}$ and cooled to room temperature prior to testing.

Fiber reinforcement of the plasterboard was done in the mixing phase. The fibers were evenly dispersed in the water, before adding the water to the mixture (gypsum + PFW). Dosages of $2 \%$ and $4 \%$ by weight of gypsum were added.

\section{Test methods}

Characterization of all the plasterboard specimens tested bulk density, flexion strength, water absorption rate, water retention capacity, and surface hardness. The instructions in Standard EN 520 (21) were followed, which establishes the specifications and the test methods for gypsum plasterboard.

The flexural strength of the plasterboard represents the maximum stress within the material prior to rupture. The $(400 \times 300 \times 15) \mathrm{mm}^{3}$ specimens were subjected to controlled loading up until fracture took place. Fiber behavior in the gypsum matrix was also evaluated through the load-displacement ratio.
Total water absorption capacity was determined as the percentage increase in the mass of a specimen were held underwater over $2 \mathrm{~h} \pm 2 \mathrm{~min}$. Percentage water retention was measured in terms of sample weight loss after oven-drying at $40{ }^{\circ} \mathrm{C}$ over $48 \mathrm{~h}$ and was determined using the following equation: Water retention $(\%)=\mathrm{Ww}-\mathrm{Wd} / \mathrm{Wd} \times 100$, where $W w$ is the wet weight of the sample and $W d$ is the weight of the sample after drying.

Shore $\mathrm{C}$ hardness determines the surface hardness of the plasterboards by establishing the indent left by an exerted force on each test specimen, measured in Shore C units, from 0 (softest) to 100 (hardest). In this test, the surface hardness of the plasterboard was defined by the exterior mark of a small steel ball dropped from a specified height.

Scanning Electron Microscopy (SEM) produced images of the interface between the different material components. A FSEM HITACHI S-4800 SEM was employed, with an acceleration current of $20 \mathrm{kV}$ and a current intensity of $201 \mathrm{~A}$, with a variable working distance, and an EDX Bruker XFlash-5030 silicon drift detector.

The thermal resistivity and the fire reaction indexes of the samples were measured. Thermal resistivity was taken from thermal conductivity results presented in previous works (15) in accordance with standard EN 12667 (22). The non-combustibility test was applied to evaluate the behavior of the samples at high temperatures, in accordance with standard EN ISO 1182 (23). The tests were conducted in an open vertical furnace (Figure 1), in which the specimen was placed within a cylindrical space with a diameter of $75 \mathrm{~mm}$ and a height of $150 \mathrm{~mm}$. During the test, the electronically controlled furnace temperature was increased at a constant rate, from room temperature to $800^{\circ} \mathrm{C}$ in $2 \mathrm{~h}$,

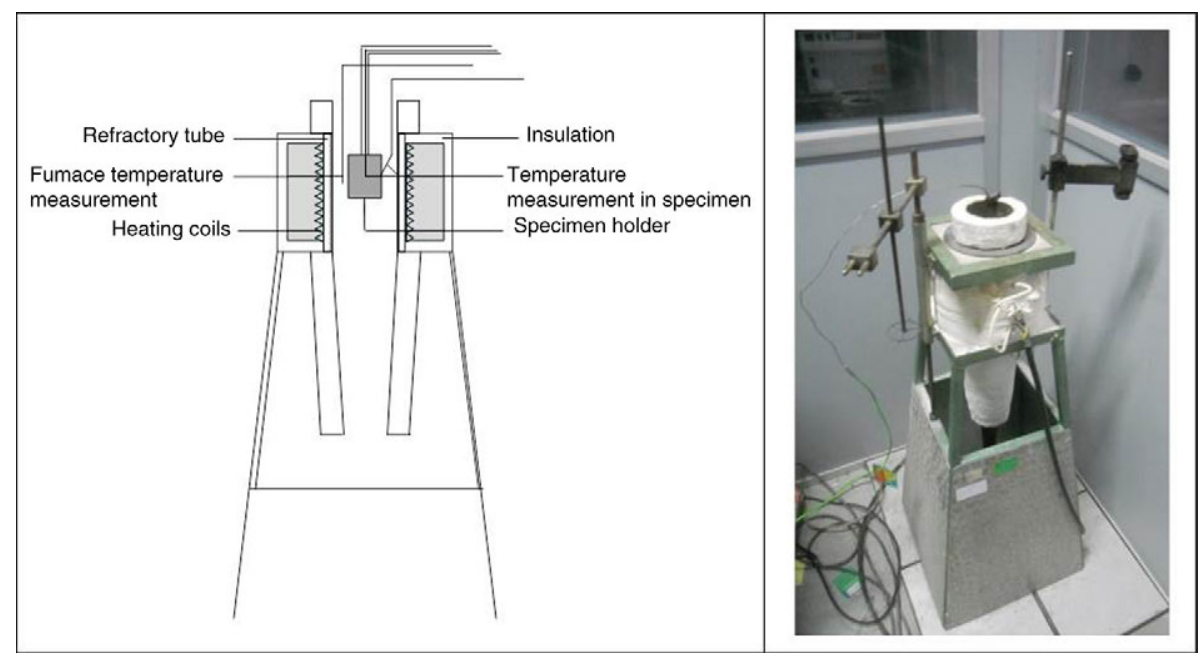

FIGURE 1. Scheme non combustibility test. 
after which it remained at $800{ }^{\circ} \mathrm{C}$ for a further 60 minutes (24). In this test, temperature increases were measured by the furnace thermocouple, the duration of flaming and the mass loss of the sample, in cylindrical samples of $45 \mathrm{~mm}$ in diameter, and $50 \mathrm{~mm}$ in height, which had previously been conditioned in a ventilated oven at temperatures of $(60 \pm 5){ }^{\circ} \mathrm{C}$, over 24 hours.

\section{RESULTS AND DISCUSSION OF CHARACTERIZATION TEST RESULTS}

\section{Bulk density}

It may be seen from the results shown in (Table 2) that the density continued to drop as further waste products were introduced in the mixture. The reduction in average density by dosage, taking GPB RS as the reference dosage, varied between $5 \%$ and $38 \%$. As the amount of polyurethane increased, larger amounts of water were necessary to ensure the workability of the mixture, which also meant an increase in the porosity of the material and, in consequence, a reduction in its bulk density. In addition, the incorporation of a material with a lower real density than the base matrix was a further fundamental factor in the reduction of the plasterboard density. The result was coherent with the characteristics of the material in use, as the polymer waste presented a real density of $1080 \mathrm{Kg} / \mathrm{m}^{3}$ as opposed to the plaster density of $2320 \mathrm{Kg} / \mathrm{m}^{3}$. This reduction in density meant a reduction in the weight by surface unit of the material, which dropped even further as more waste was incorporated in the composition of the plasterboard. Accordingly, a reduction as high as $48 \%$ in the weight/surface ratio was obtained for the GPB2 sample with regard to GPB RS. The incorporation of $2 \%$ fibers in the mixtures involved no significant variation with regard to the density of the compound material, which was similar in all cases. However, the density increased from $2-8 \%$ at higher percentages $(4 \%)$. In comparison with the standard series, an increase in bulk density that ranged from $94 \%$ for reference gypsum plasterboard (GPB RS 4F2) to 38\% for dosages with high polyurethane contents (GPB2 4F2) in the case of Series III (with $4 \%$ of PP fibers) was observed. This increased density may be due to the specific additives and aggregates of the commercial gypsum board, which were not applicable to the plasterboard used in this study.

If we establish a relationship between bulk density and water absorption, water absorption increased, as was expected, when the bulk density of the GPBPFW samples decreased. This may be explained by the increasing demand for water as the percentages of polymer increased, which leads to higher porosity in the plasterboard.

\section{Flexural strength (measured as breaking load flexion)}

The flexural strengths of the specimens with different polyurethane contents, both with and without fibers, are shown in (Figure 2). The breaking load decreased with the increase in the quantity of polyurethane waste. This reduction in resistance might be related to the lower content of gypsum in the samples, which represents the structural skeleton of the composite material (25). The breaking load appeared to increase with the addition of polypropylene fibers. A $2 \%$ presence of fibers led to improvements in the performance of the plasterboard in comparison with the plasterboard without fibers; rising from $5 \%$ in GPB 0.5 to $10 \%$ in GPB1. A 4\% presence of fibers was needed for any further increase in the breaking load under flexion. The incorporation of larger amounts of waste progressively strengthened the plasterboard, up until dosages of equal parts (1/1); moving from $11 \%$ in $(0.5 / 1)$ mixtures to $24 \%$ in $(1 / 1)$ mixtures. However, the influence of variations in the percentage of polypropylene fibers on flexural strength, in dosages with higher amounts of polyurethane (2/1), was not so clear. This result was probably due to the high polymer (PP and PFW) content in such a small thickness $(15 \mathrm{~mm})$ of board. There was no significant improvement of plasterboards with fibers, but without polyurethane (RS), which may probably be explained in terms of the elastic modulus of the compound. Further research similar to other studies in the literature (26) would be necessary in this field to find an explanation for this effect.

If we compare the results of the gypsum plasterboard in mixtures (1/1) with fibers (GPB1 F2) with those of the commercial boards (GPB ST), in a transversal sense, values of around $16 \%$ and less for fracture loads under flexion were obtained. So, the results were acceptable up until dosage (1/1), all the more so as the boards in this study had no paper

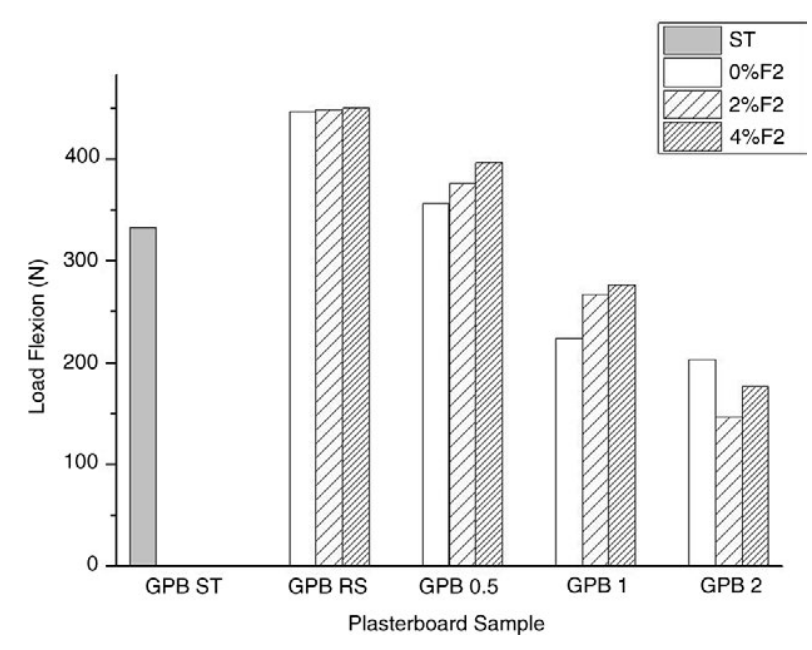

FIGURE 2. Breakind load flexion. 
lining and no additives, which therefore implies weaker mechanical properties in comparison to the commercial gypsum board.

\section{Load versus displacement}

An important aspect of this work consisted in determining the behavior of gypsum plasterboard prepared with polyurethane foam wastes, so as to examine the practical application of these recycled materials in prefabricated elements for use in interior partitioning. However, only those boards reinforced with polypropylene fibers (F2) could be selected, and, from among them, those with the most significant physical performance (GPB1).

The relationship between load versus displacement of gypsum plasterboard with polyurethane (GPB1) and PP fibers $(0 \%, 2 \%$ and $4 \%)$ is shown in (Figure 3 ). It may be seen from the results that creep increased in proportion to the increase in fiber amounts in each dosage, up until breakage, when the plasterboard was unable to withstand further loading. This effect is very important, as the elastic properties of the material actually increased. Another interesting point observed during the fracture load test under flexion

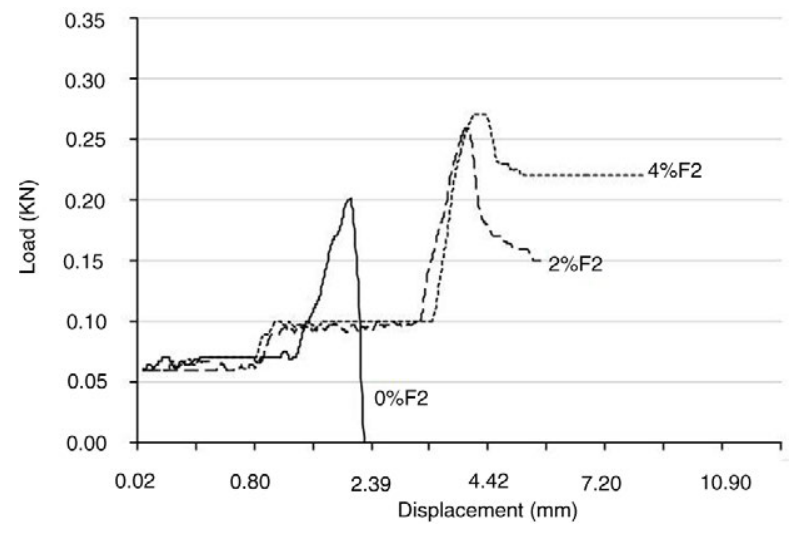

Figure 3. Load versus displacement of GPB 1 and PP fibers. was the maintenance of the fracture load over time in series GPB1 4F2. The implicit assumption in these results is that the new mixed material is flexible, in dosages with a ratio of $1 / 1$ and $4 \%$ of PP fibers; even after breakage, the plasterboard continued to show the sort of resilient behavior that could reduce the risk of panel collapse $(27,28)$.

A good internal structure of the matrix and its components can be seen in the SEM images (Figure 4-a), in which the polyurethane waste is surrounded by a crystalline gypsum structure that gives it a solid bond of great stability. The images of the GPB1 4F2 sample show the presence of polyurethane films inside the matrix, the continuity of which appears to be interrupted by the majority presence of gypsum crystals.

In (Figure 4-b), fiber bonding with the gypsum matrix may be seen, in which the fibers show acceptable adherence to the gypsum-polyurethane matrix.

\section{Surface hardness}

Increased dosages of the waste implied a reduction in the surface hardness of the material. It may be seen that the diameter of the surface imprint increased when the mixture incorporated higher amounts of waste (Table 2). This increase in imprint size is perhaps due to the existence of a larger percentage of pores, which supports the possibility that these compounds may be penetrated or incised by other material. Reductions of surface hardness of up to $47 \%$ occurred in samples GPB2 in relation to the reference specimens (GPB RS). (Figure 5) shows the relationship between the surface hardness results obtained in this work and the Shore $\mathrm{C}$ hardness results obtained in previous studies on $40 \times$ $40 \times 160 \mathrm{~mm}^{3}$ specimens (15). A correlation between both parameters was observed, indicating good proportionality with a fit to a polynomial line $\left(\mathrm{R}^{2}=\right.$ 1). If we compare the hardness results of both the GPB PFW samples and the commercial boards, an increase of $9 \%$ was observed in the GPB2 gypsum plasterboards.
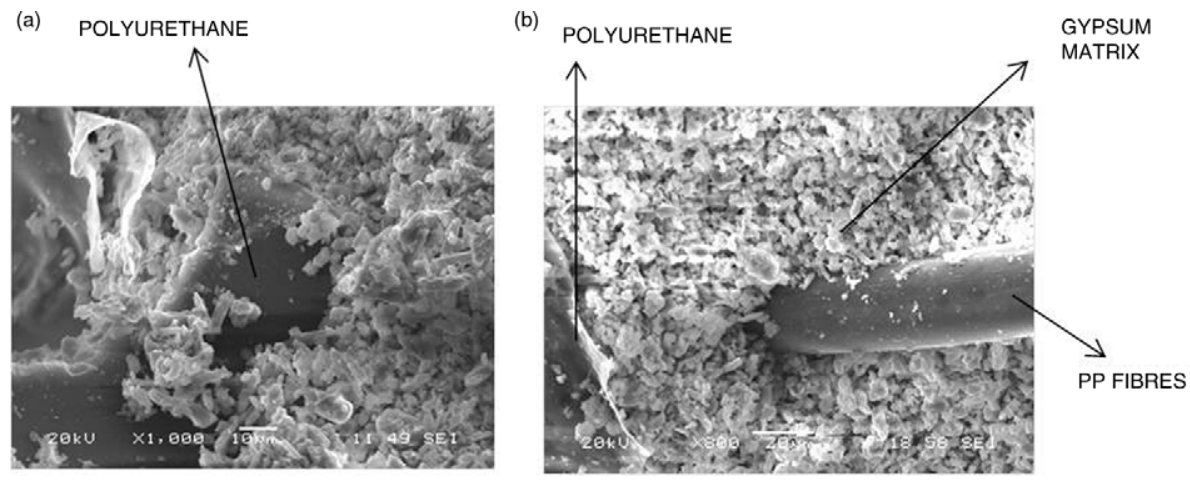

FIGURE 4. SEM of GPB1 4F2 Sample. 


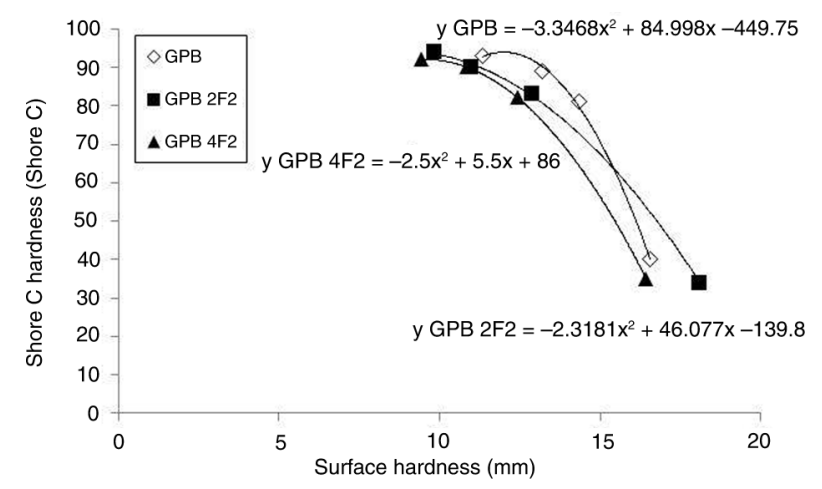

Figure 5. Shore $\mathrm{C}$ versus Surface hardness.

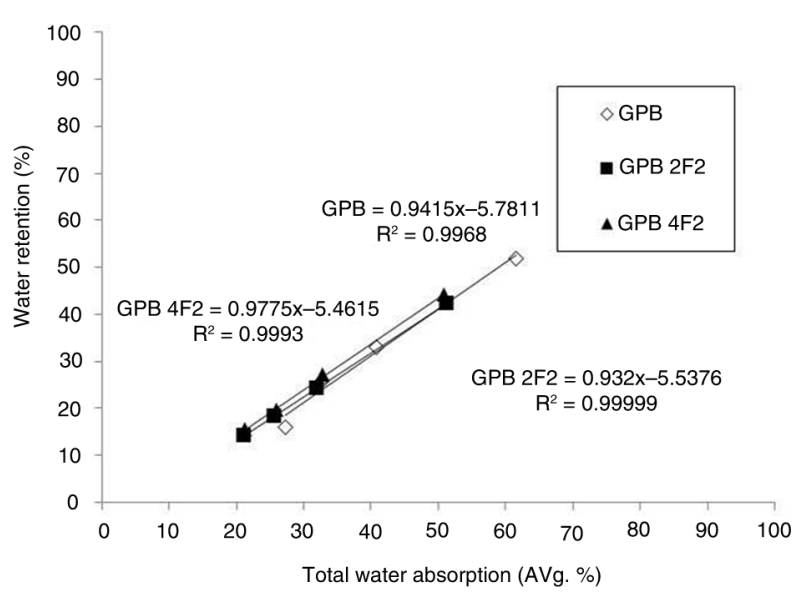

FIGURE 6. Relationship between total water absorption and water retention of GPB.

\section{Total water absorption and water retention}

With regard to the total water absorption test, the results show that a percentage of the average total absorption of the different dosages increased in line with the incorporation of higher proportions of polyurethane waste.

As shown in (Table 2), the increased presence of waste in the mixture implied greater water absorption. This capacity increased considerably in the case of the GPB2 plasterboards (60\%); $50 \%$ greater than in the commercial plasterboard.

The absorption capability of the boards was reduced when fibers were introduced in the mixture; to such a point that their percentages were hardly significant. For example, in dosage $(0.5 / 1)$ with fibers at $2 \%$, the absorption percentage was around $25.59 \%$, very similar to the $26 \%$ of the GPB0.5 4F2, but less than the reference dosage GPB0.5. If the reduction of the absorption by dosages is calculated in percentage terms (\%), it is notable that the reductions in absorption stood at around $20 \%$, both for the family of reference specimens RS and for mixtures (0.5/1) and (1/1), at fiber percentages of $2 \%$ and $4 \%$. In the $(2 / 1)$ mixtures, the absorption rates fell slightly less, at any fiber concentration, by around $17 \%$. This reduction in total absorption capability is explained by the hydrophobic characteristics of the polypropylene fibers (29). A relation between the water retention capacity of the material and the results of water absorption was established for GPB with different proportions of fibers (Figure 6). A correlation between both parameters may be seen in all samples, which varies in a proportional way, following a linear-type tendency, in accordance with the equations shown in (Figure 6).

\section{THERMAL PROPERTIES}

Over recent years, a great deal of effort has gone into promoting energy efficiency in buildings, with new regulations on mandatory insulation of the external envelope. An effective way of saving energy is to improve the thermal insulation of buildings by applying insulative materials to walls and floors (30). However, these kinds of materials must show acceptable fire retardant behavior, which can be measured in terms of the flammability of the material in the presence of fire. In this study, the non-combustibility test provided data on the combustibility of the gypsum plasterboard.

\section{Thermal resistivity}

One way of measuring the insulative capabilities of gypsum plasterboard is through the determination of its thermal conductivity. This parameter has been determined in earlier studies (15), in which the analysis of the thermal resistivity of gypsum plasterboard samples in relation to their densities were shown to correlate well. In all cases, the incorporation of the waste in the mixtures produced a reduction in the weight per surface and an improvement in the thermal resistance and the insulative capacity of the material. This improvement was not only due to the lower density of the material, but was also dependent on the type of waste. Consequently, the GPB with PFW plasterboards, characterized by their closed cell structures with a lower thermal conductivity coefficient than the other waste products, showed the best behavior (31).

On the other hand, when compared with the specifications of other commercial prefabricated elements, such as commercial standard gypsum plasterboard (GPB ST), it was found that for dosage $(2 / 1)$, reference values of over $0.060 \mathrm{~m}^{2} \cdot \mathrm{K} / \mathrm{W}$ were reached (Table 3). Thus the values obtained were similar to other construction materials used in partition walls. 
TABLE 3. Thermal resistivity of conventional prefabricated materials e $=15 \mathrm{~mm}(32)$

\begin{tabular}{lcc}
\hline Sample & Density $\left(\mathbf{K g} / \mathbf{m}^{\mathbf{3}}\right)$ & Thermal resistivity $\left(\mathbf{m}^{\mathbf{2}} \cdot \mathbf{K} / \mathbf{W}\right)$ \\
\hline Commercial gypsum plasterboard (GPB ST) & 753 & 0.060 \\
Cellular concrete prefabricated & 800 & 0.065 \\
Prefabricated concrete with expanded clay & 700 & 0.068 \\
\hline
\end{tabular}

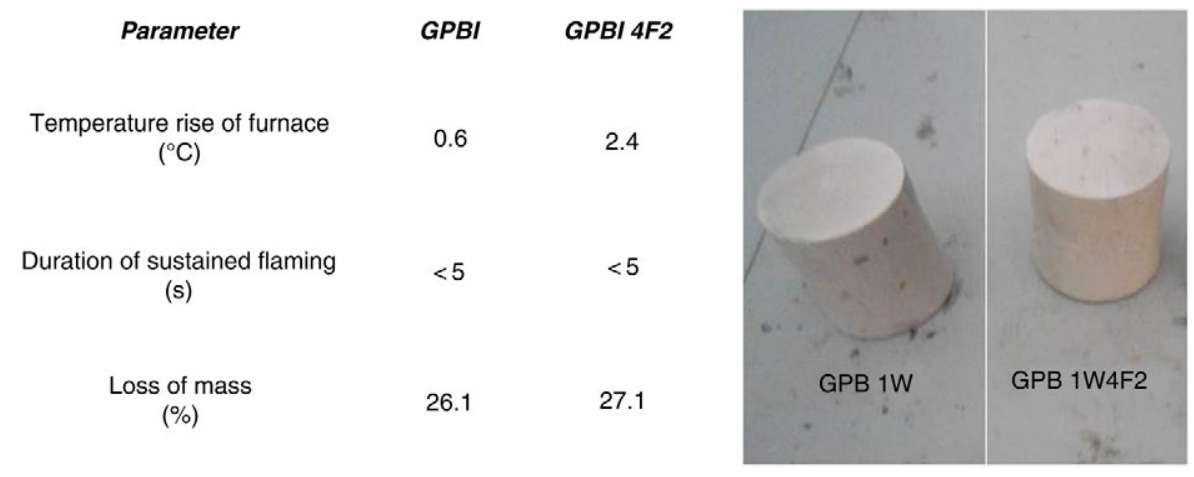

FIGURE 7. Non combustibility test results_EN.

\section{Reaction to fire performance}

The thermal behavior of the samples, confirmed by the non-combustibility test, gives us an idea of their fire retardance properties. The results of the non-combustibility test (Figure 7) confirmed that the samples that incorporated polyurethane in their composition, and specifically, the GPB1 sample, presented flaming times of less than 20 seconds with a temperature increase of below $50{ }^{\circ} \mathrm{C}$ and losses of less than $50 \%$ in their mass. This result indicated that even if we only take the contribution of the materials to fire reaction into account, their composition corresponded to Euroclass A2 (non-combustible) in accordance with the European fire reaction classification of building materials for homogeneous products (33). In the case of the plasterboard with polyurethane foam waste fibers at 4\% (GPB1 4F2) the fire behavior was similar to the results of the sample without fibers, with a Euro class A2 classification. Other researchers have noted the good behavior of polypropylene fibers and their contribution to the development of fire resistant materials (34). However, the non-combustibility test is not sufficient to classify examples that include polyurethane components. CTE D-SI validation of sample GPB1 as (B-s2-d0) (35) may require an assessment of its performance in accordance with EN ISO 1716 (36) to determine gross calorific value and the EN 13823 (SBI) test (37). Nevertheless, if we take Spanish Royal Decree 110/2008143 (38) as a reference, then a plasterboard system mechanically fixed to a metallic substructure with Euro class type E insulation (40 $\mathrm{mm}$ polyurethane foam) is classified as (B-s1, d0). On that basis, we may affirm with a degree of certainty that the new material, having been placed as interior plasterboard on a doublelayer dividing wall, will comply with all specifications in the relevant legislation.

\section{CONCLUSIONS}

A study involving the manufacture of gypsum plasterboard that incorporates polyurethane waste aggregates reinforced with polypropylene fibers has been presented in this paper.

1. Reductions in the bulk density of the material were in all cases obtained, which were greater when larger amounts of waste were included in the final mixture. In turn, the weight/surface ratio yielded reductions of up to $48 \%$ of the GPB 2 type material, which implies a significant reduction in weight for the installation of prefabricated products.

2. The maximum breaking load under flexion fell progressively as larger amounts of polyurethane waste were included. This reduction was linked to the lower content of gypsum in the final matrix of the composite mixture. The inclusion of fibers in the gypsum matrix improved the mechanical behavior of the material, raising its breaking load and extending its creep behavior, whereby the elastic behavior of the material prevents its collapse and prolongs its working time. SEM images of the gypsum-waste interlocking with the fiber matrix showed good adhesion between both components. A strong 
physical bond was also observed between the three materials that ensured good stability of the composite.

3. Total water absorption was directly proportional to the water retention capacity of the material and was better in the mixtures that incorporated the polyurethane waste. The incorporation of fibers reduced this capability, probably due to the hydrophobic characteristics of the polypropylene fibers, which initially absorbed water before expulsing it during the setting process.

4. There was a good correlation between the values obtained with other surface hardness measurement techniques which allowed us to predict hardness values for other types of mixtures with polymer waste products. The values were comparable to those of the commercial plasterboard.

5. The fire reaction performance of the plasterboard that incorporated polyurethane in a (1/1) ratio presented good behavior in terms of its temperature increase in the oven. The sample presented no flammable properties. Its use as a construction material for internal linings may therefore be considered to comply with the Spanish Building Code (CTE DB-SI), highlighting the potential use of this new material in internal linings.

\section{REFERENCES}

1. Chwieduk, D. (2003) Towards sustainable-energy buildings. Appl Ener. 76 [1-3], 211-17. http://dx.doi.org/10.1016/ S0306-2619(03)00059-X

2. Medineckiene, M.; Turskis, Z.; Zavadskas, E.K. (2010) Sustainable construction taking into account the building impact on the environment. $J$ Environ Eng Landscape Manag. 18 [2], 118-27. http://dx.doi.org/10.3846/ jeelm.2010.14

3. Broun, R.; Menzies, G. (2011) Life cycle energy and environmental analysis of partition walls systems in UK. Procedia Eng. 21, 864-73. http://dx.doi.org/10.1016/ j.proeng.2011.11.2088

4. Rodríguez-Orejón, A.; Del Río-Merino; M., FernándezMartínez, F. (2014) Characterization mixtures of thick gypsum with addition of treated waste from laminated plasterboards. Mater. Construcc. 64 [314], 1-7. http://dx.doi. org/10.3989/mc.2014.03413

5. Serna, A.; Del Río, M.; Gabriel Palomo, J.; González, M. (2012) Improvement of gypsum plaster strain capacity by the addition of rubber particles from recycled tyres. Constr Build Mater. 35, 633-41. http://dx.doi.org/10.1016/j. conbuildmat.2012.04.093

6. Tadeu, A.; Moreira, A.; António, J.; Simões, N.; Simões, I (2014) Thermal delay provided by floors containing layers that incorporate expanded cork granule waste. Energ Build. 68, 611-9. http://dx doi.org/10.1016/j.enbuild 2013.10.007

7. Ahmed, A.; Ugai, K.; Kame, T. (2011) Investigation of recycled gypsum in conjunction with waste plastic trays for ground improvement. Constr Build Mater. 25, 208-17. http://dx.doi.org/10.1016/j.conbuildmat.2010.06.036

8. Rodríguez, A.; Gutiérrez-González, S.; Horgnies, M.; Calderón, V. (2013) Design and properties of plaster mortars manufactured with ladle furnace slag. Mater Des. 52, 987-94. http://dx.doi.org/10.1016/j.matdes.2013. 06.041
9. Smakosz, Ł.; Tejchman, J. (2014) Evaluation of strength, deformability and failure mode of composite structural insulated panels. Mater Des. 54, 1068-82. http://dx.doi. org/10.1016/j.matdes.2013.09.032

10. Melo, M.O.B.C.; Da Silva, L.B.; Coutinho, A.S.; Sousa, V.; Perazzo, N. (2012) Energy efficiency in building installations using thermal insulating materials in northeast Brazil. Energ Build. 47, 35-43. http://dx.doi.org/10.1016/j. enbuild 2011.11.021

11. González Madariaga, F.J.; Lloveras Macia, J. (2008) EPS (expanded polystyrene) recycled blends mixed with plaster or stucco, some applications in building industry. Inf Constr. 60 [509], 35-43.

12. Herrero, S.; Mayor, P.; Hernández Olivares, J. (2013) Influence of proportion and particle size gradation of rubber from end-of-life tires on mechanical, thermal and acoustic properties of plaster-rubber mortars. Mater Des. 47, 633-42. http://dx.doi.org/10.1016/j. matdes.2012.12.063

13. Alonso, J.A.; Reyes, E.; Gálvez, J.C. (2013) Study of the cracking of sandwich panels of plasterboard and rockwool. Mater. Construcc. 63 [311], 403-421. http://dx.doi.org/ 10.3989/mc.2013.01412

14. Agulló, L.; Aguado, A.; Garcia, T. (2006) Study of the use of paper manufacturing waste in plaster composite mixtures. Build Environ. 41 [6], 821-7. http://dx.doi. org/10.1016/j.buildenv.2005.03.011

15. Gutiérrez-González, S.; Gadea, J.; Rodríguez, A.; Junco, C.; Calderón, V. (2012) Lightweight plaster materials with enhanced thermal properties made with polyurethane foam wastes. Constr Build Mater.28, 653-8. http://dx.doi. org/10.1016/j.conbuildmat.2011.10.055

16. Eve, S.; Gomina, M.; Orange, G. (2004) Effects of polyamide and polypropylene fibres on the setting and the mechanical properties of plaster. Key Eng Mater. 264268, 2531-6. http://dx.doi.org/10.4028/www.scientific.net/ KEM.264-268.2531

17. Eve, S.; Gomina, M.; Hamel, J.; Orange, G. (2006) Investigation of the setting of polyamide fibre/latex-filled plaster composites. J Eur Ceram Soc. 26, 2541-6. http:// dx.doi.org/10.1016/j.jeurceramsoc.2005.07.063

18. Liu, K.; Wu, Y-F.; Jiang, X.L. (2008) Shear strength of concrete filled glass fiber reinforced gypsum walls. Mater Struct. 41 [4], 649-62. http://dx.doi.org/10.1617/ s11527-007-9271-8

19. EN 13279-1:2008. Gypsum binders and Gypsum Plasters. Part 1: Definitions and requirements.

20. EN 13279-2: 2005. Gypsum binders and gypsum plasters Part 2: Test methods

21. EN 520: 2005 + A1. Gypsum plasterboards. Definitions, specifications and test methods.

22. EN 12667:2001. Thermal performance of building materials and products. Determination of thermal resistance by means of guarded hot plate and heat flow meter methods. Products of high and medium thermal resistance.

23. EN ISO 1182:2010. Reaction to fire tests for building products - Non-combustibility test

24. Ciudad, A.; Lacasta, A.M.; Haurie, L.; Formosa, J.; Chimenos, J.M. (2011) Improvement of passive fire protection in a gypsum panel by adding inorganic fillers: Experiment and theory. Appl Therm Eng. 31, 3971-8. http:// dx.doi.org/10.1016/j.applthermaleng.2011.07.048

25. Panesar, D.K.; Shindman, B. (2012) The mechanical, transport and thermal properties of mortar and concrete containing waste cork. Cem Concr Compos. 34, 982-92. http:// dx.doi.org/10.1016/j.cemconcomp.2012.06.003

26. Vasconcelos, G.; Lourenço, P.B.; Camões, A.; Martins, A.; Cunha, S. (2015) Evaluation of the performance of recycled textile fibres in the mechanical behaviour of a gypsum and cork composite material. Cem Concr Compos. 58, 29-39. http://dx.doi.org/10.1016/j. cemconcomp.2015.01.001

27. Gencela, O.; del Coz Diaz, J.J.; Sutcuc, M.; Koksald, F.T.; Alvarez Rabanalb, F.P.; Martinez-Barrerae, G.; Brostowf, W. (2014) Properties of gypsum composites containing vermiculite and polypropylene fibers: Numerical and 
experimental results. Energ Build. 70, 135-44. http://dx.doi. org/10.1016/j.enbuild.2013.11.047

28. Jarabo, R.; Fuente, E.; Monte, M.C.; Mutjé, P.; Negro, C. (2012) Use of cellulose fibers from hemp core in fibercement production. Effect on flocculation, retention, drainage and product properties. Ind Crops Prod. 39, 89-96. http://dx.doi.org/10.1016/j.indcrop.2012.02.017

29. Aghazadeh, J.; Sangghaleh, A.; Nazaric, A.; Pourjavad, N. (2011) Analytical modeling of strength in randomly oriented PP and PPTA short fiber reinforced gypsum composites. Comp Mater Sci. 50 [5], 1619-24. http://dx.doi. org/10.1016/j.commatsci.2010.12.020

30. Dubois, S.; Lebeau, F. (2013) Design, construction and validation of a guarded hot plate apparatus for thermal conductivity measurement of high thickness crop-based specimens. Mater Struct. 48[1-2] 407-21. http://dx.doi. org/10.1617/s11527-013-0192-4

31. Gutiérrez-González, S.; Gadea, J.; Rodríguez, A.; Blanco-Varela, M.T.; Calderón, V. (2012) Compatibility between gypsum and polyamide waste to produce lightweight plaster with enhanced thermal properties. Constr Build Mater. 34, 179-85. http://dx.doi.org/10.1016/j. conbuildmat.2012.02.061

32. EN 12524:2000. Building materials and products. Hygrothermal properties. Tabulated design values.

33. Commission Decision of 8 February 2000 implementing Council Directive 89/106/EEC as regards the classification of the reaction to fire performance of construction products. Official Journal of the European Communities No L 50. 23.2.2000.

34. Binici, H.; Aksogan, O.; Nuri Bodur; M.; Akca, E.; Kapur, S. (2007) Thermal isolation and mechanical properties of fibre reinforced mud bricks as wall materials. Constr Build Mater. 21, 901-6. http://dx.doi.org/10.1016/j. conbuildmat.2005.11.004

35. Spanish Building Code (CTE DB-SI).

36. EN ISO 1716:2010. Reaction to fire tests for products Determination of the gross heat of combustion (calorific value).

37. EN 13823-SBI: 2002. Fire technical testing of building products.

38. REAL DECRETO 110/2008, de 1 de febrero. 